<総 説 $>$

(受理 : 平成 28 年 6 月 30 日)

\title{
剛直骨格を有するエポキシ樹脂の熱的性質と網目鎖構造 Thermal Property and Networked Structure of Epoxy Resins with Rigid Structure
}

原田 美由紀*

Miyuki HARADA

\section{1.はじめに}

代表的なネットワークポリマーの一つであるエポキシ樹 脂は, 形成される架橋構造によって, 硬化物の熱的・力学 的特性が大きく影響されることが知られている11。硬化物 が示す物性バランスの良さのため，従来から工業的に広範 に用いられてきたが，近年の用途の多様化や要求性能の向 上に対応するため，更なる高性能・高機能化への取り組み が急務となっている。

剛直なメソゲン基を骨格に有する液晶性エポキシ樹脂は, 汎用骨格のエポキシ樹脂とは大きく異なる特徵を示す。そ れは，同一組成のエポキシ・硬化剤の組み合わせであって 屯，形成されるネットワーク鎖の高次構造が硬化条件によっ て大きく变化するためである。すなわち，液晶性エポキシ 樹脂を用いることで網目鎖の立体的な構造制御が可能とな $り^{2 \sim 5)}$ ，ネットワークポリマーの更なる高性能化や新規な 機能性の発現が期待される。ここではこれらの一部を紹介 することとする。

\section{2. 高 $\mathrm{Tg}$ を示す剛直骨格エポキシ樹脂}

剛直構造の導入によって，ネットワークポリマーの熱的 性質を向上できることはよく知られているが，高 $\mathrm{Tg}$ 化の 要求は近年益々高まっている。有田ら ${ }^{6)}$ は，ナフタレン型 4 官能エポキシを合成し，その硬化物が $300^{\circ} \mathrm{C}$ 以上の高 $\mathrm{Tg}$ を示すことを報告している（表 1)。また，反応条件の最 適化によって, 図 1 に示すような, 三量体のナフチレンエー

\footnotetext{
* 関西大学 化学生命工学部

大阪府吹田市山手町 3-3-35 $=564-8680$

Faculty of Chemistry, Materials and Bioengineering, Kansai University

3-3-35, Yamate-cho, Suita, Osaka 564-8680, Japan (平成 28 年度日本接着学会進歩賞受賞)
}

表 1 ナフタレン型 4 官能エポキシ樹脂の硬化物性

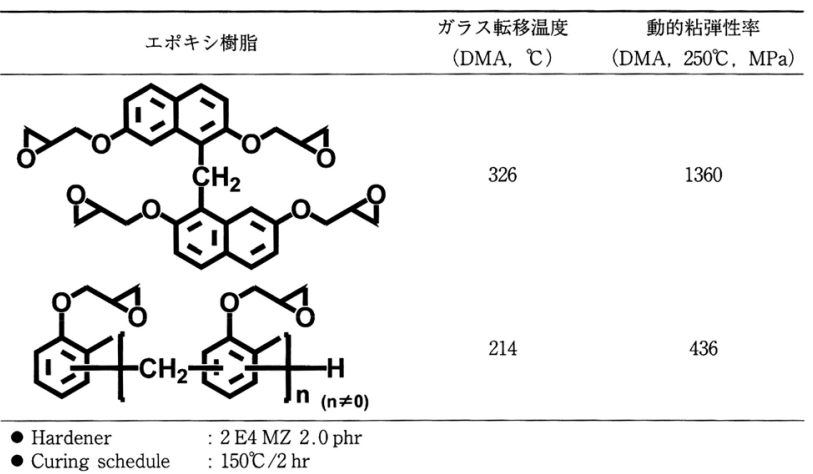

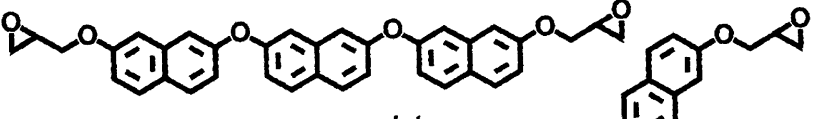 \\ mixture

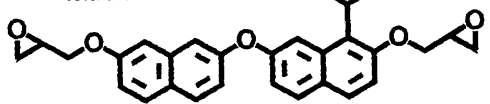

図 1 三量体のナフチレンエーテルオリゴマー型エポキシの 化学構造

テルオリゴマー型エポキシ樹脂の選択的な合成に成功し， 高 $\mathrm{Tg}$ と難燃性の両立が可能であることを報告している。 これは剛直なナフタレン構造の熱安定性とグラファイト状

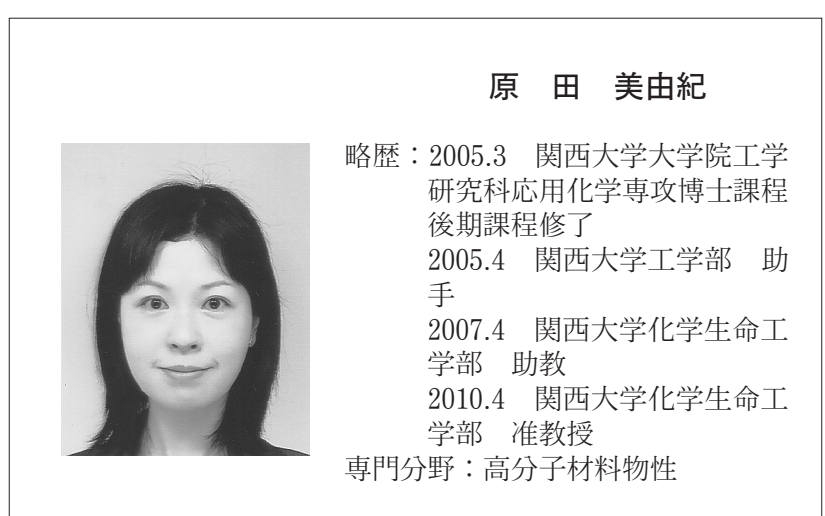




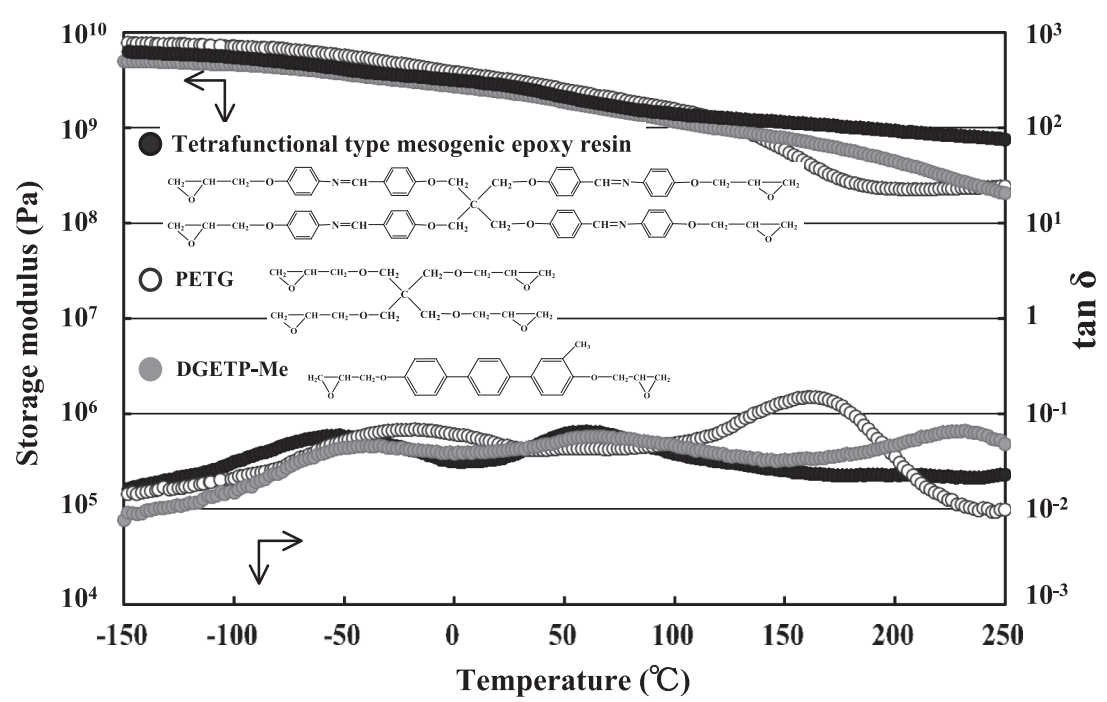

図 24 官能メソゲン骨格エポキシ樹脂の動的粘弾性挙動

の炭化発泡層の形成によって達成される。また，剛直構造 でありながら, 溶剤溶解性も高く, 平面構造を有するナフ タレン骨格によって低膨張性を示すという特徵も併せ持つ。

筆者らは, メソゲン基と多官能構造の導入による高 $\mathrm{Tg}$ 化について報告している。分子の中心に分岐構造を有する 四官能型テトラメソゲンエポキシ樹脂の等方相硬化物は, $250^{\circ} \mathrm{C}$ までの幅広い温度範囲に打いて, Tg に起因する $\tan \delta$ ピーク及び貯蔵弾性率の急激な低下はほとんど観察されな ( 7)（図 2)。メソゲン基を含まない四官能性エポキシ樹脂 （PETG）硬化物や，メソゲン基濃度が同程度（約 50\%） である DGETP-Me 硬化物と比較しても， $150^{\circ} \mathrm{C}$ 以上の高 温領域において高い貯蔵弾性率を維持した。分岐構造の導 入や架橋点の増加だけでなく, 剛直構造であるメソゲン基 を共存させることにより，網目鎖全体の分子運動性が抑制 されたものと考えられる。

また，骨格に環状シロキサン構造を導入し，液晶エポキ シモノマーの低融点化と硬化物の耐熱性向上を試みた ${ }^{8)}$ 。 鎖状シロキサン構造を導入した等方相硬化物の $\mathrm{Tg}$ が $104^{\circ} \mathrm{C}$ であったのに対し，環状シロキサン構造を導入した等方相 硬化物には明瞭な $\tan \delta$ ピークが観察されなかった（図 3 )。

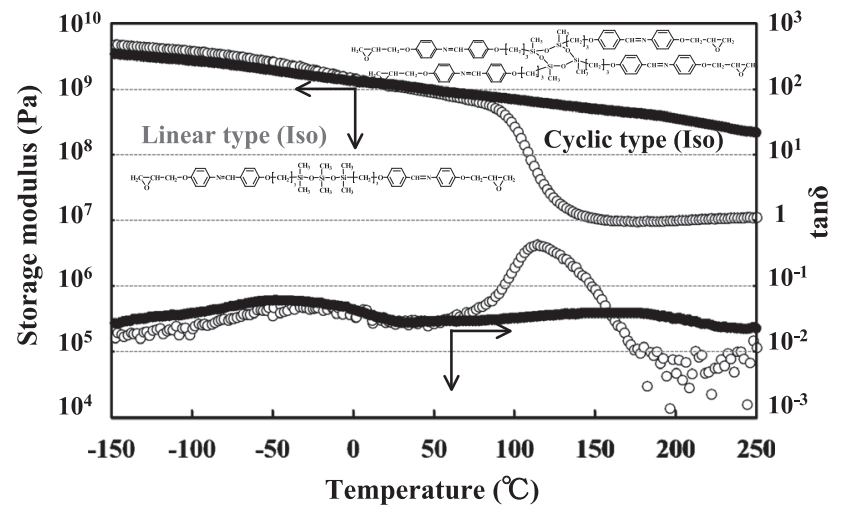

図 3 環状及び鎖状シロキサン型メソゲン骨格エポキシ樹脂 の動的粘弾性挙動
これは, 環状シロキサン構造の導入による網目鎖の分子運 動性の低下や架橋点の増加による密なネットワークの形成 に起因するものと考えられる。また，モノマー状態におい ては, シロキサン構造の運動性によって $\mathrm{T}_{\mathrm{m}}: 95^{\circ} \mathrm{C}$ という 低融点化が達成される一方で, 硬化後は環状構造が架橋点 のような役割として作用したことが，低融点化と高 $\mathrm{Tg}$ の 両立を達成した要因であると推測される。また，硬化物の 引張試験を行ったところ, 鎖状シロキサン系（破壊エネル ギー：128 kJ $/ \mathrm{m}^{2}$ ) と比較して, 弾性率・破断強度の向上 之破断歪みの低下が観察されたが，破壊エネルギーは $101 \mathrm{~kJ} / \mathrm{m}^{2}$ となり同程度の值を維持した。これらのこと から, 高 $\mathrm{Tg}$ 之高強鞀性の両立が達成された高性能エポキ シ樹脂が得られたものと考えられる。また， $p$-フェニレ ンジアミンを用いて得られた液晶相硬化物（図 4）では, TEM 観察から液晶相の体積分率が高いポリドメイン構造 を形成していることが明らかとなった。一般に，強勒性や 熱伝導性は等方相硬化物よりも液晶相硬化物で大幅に向上 することが知られている。本硬化系に抏いても，液晶硬化

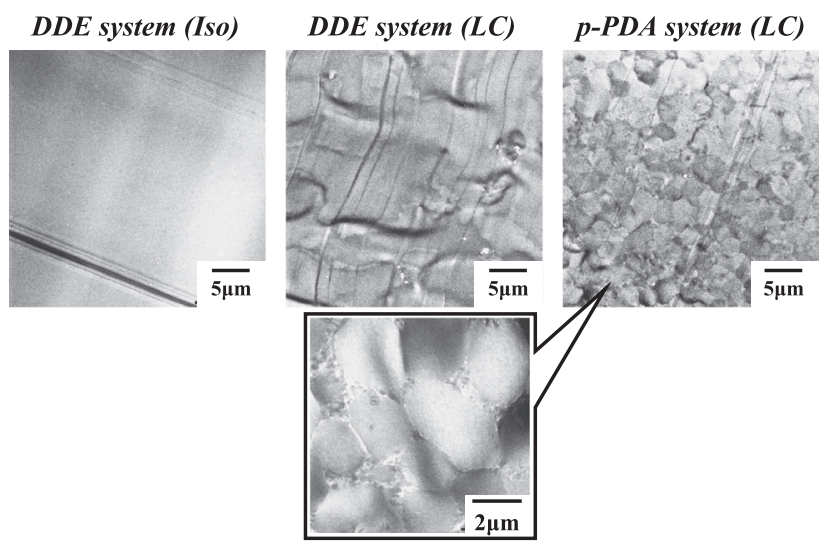

図 4 環状シロキサン型メソゲン骨格エポキシ樹脂の等方相 （DDE 硬化）及び液晶相（DDE・ $p-\mathrm{PDA}$ 硬化）硬化 物の TEM 写真 $\left(\mathrm{OsO}_{4}\right.$ により染色) 
物とすることで高 $\mathrm{Tg}$ だけでなく，強勒性や熱伝導性が向 上することが明らかとなった。

\section{3. 低融点化メソゲン骨格エポキシ樹脂}

先にも述べたように，メソゲン骨格を持つ液晶性エポキ シは高融点であることが多いため, 融点の低下を目的とし て柔軟スペーサーや非対称構造が導入されることが多い。

ツインメソゲン型エポキシ樹脂は，二つのメソゲン基を 柔軟なスペーサーを介して結合させた構造を有するエポキ シ樹脂である。スペーサーの導入によって可動性が向上し, 融点の低下や硬化物の強勒性が改善されることが知られて いる。特にアルキルスペーサーを導入したエポキシモノマー は Even-Odd 効果を示し ${ }^{9)}$ ， アルキル炭素数が奇数の時 には結晶性が低下するが，偶数では高結晶性となり融点は 非常に高くなる（図 5)。これは，二つのメソゲン基の立 体配置がスペーサーの炭素数に大きく依存するためである。 これに対して，シロキサン鎖をスペーサーとして導入した ッインメソゲンエポキシ樹脂は，アルキル鎖に比べて可動 性の高いエーテル結合を含むことからモノマーの融点低下 に及ぼす影響が大きく，Even-Odd 効果を発現しない。 筆者らがトリシロキサン及び同程度の鎖長のアルキル鎖を 導入したツインメソゲンエポキシ樹脂を合成したところ ${ }^{10)}$, アルキル型の融点 $192^{\circ} \mathrm{C}$ に対し，トリシロキサン型では $138^{\circ} \mathrm{C}$ となり約 $50^{\circ} \mathrm{C}$ の大幅な融点の低下が観察された。

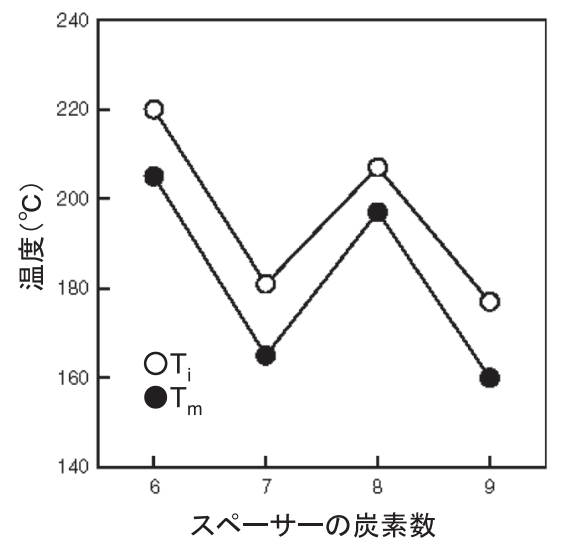

図 5 アルキルスペーサーを有するッインメソゲン型 液晶性エポキシの転移温度

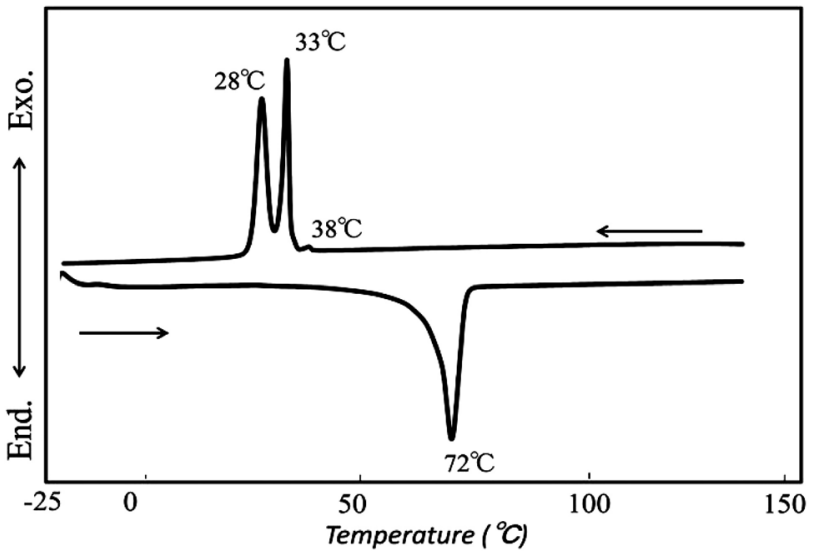

図 7 スチルベン骨格の両端にスペーサーを導入した エポキシ (DGE (C2-MS-C2)) の DSC

また，Yamamoto ら 11) はスチルベン骨格の両端にエチレ ンオキシスペーサーを導入する（図 6）ことで， $40^{\circ} \mathrm{C}$ 付近 でネマチック液晶を示す液晶性エポキシ樹脂の合成に成功 している（図 7)。一方で，スペーサーの可動性が大きす ぎると，メソゲン基の配列性を低下させるとともに，硬化 物中のスペーサー濃度の増加による Tg 低下の問題などが 生じるため，目的の特性に対する最適化が必要である。

また, Wang ら ${ }^{12)}$ はビフェニルとフェニルェステルから なるメソゲン基を導入したエポキシモノマーが $140 \sim 190^{\circ} \mathrm{C}$ （冷却過程）でネマチック液晶を示すことを，XiaO ら ${ }^{13)}$ は非対称メソゲンとアルキルスペーサー導入の併用によっ て 85〜 $145^{\circ} \mathrm{C}$ でネマチック液晶を示すことを報告している。 このような非対称構造のメソゲン基を有するエポキシ樹脂 の合成についての報告例はあるが，ネマチック液晶配列の みを示すことが多い。

\section{4. メソゲン基の配列構造形成過程の追跡}

筆者らは，大型放射光施設 SPring -8 における時分割 SAXS・WAXS 同時測定によって，メソゲン骨格液晶性 エポキシ樹脂の硬化過程における配列構造形成の過程を追 跡している ${ }^{14)}$ 。SAXS 測定において観察されたピーク強度 の経時変化を，エポキシ基の反応率执よびゲル分率測定結 果と合わせて図 8 に示す。SAXS 測定では, 反応開始後 約 3〜6 分の間に $q=2.3 \mathrm{~nm}^{-1}(27 \AA)$ のピークが出現し,
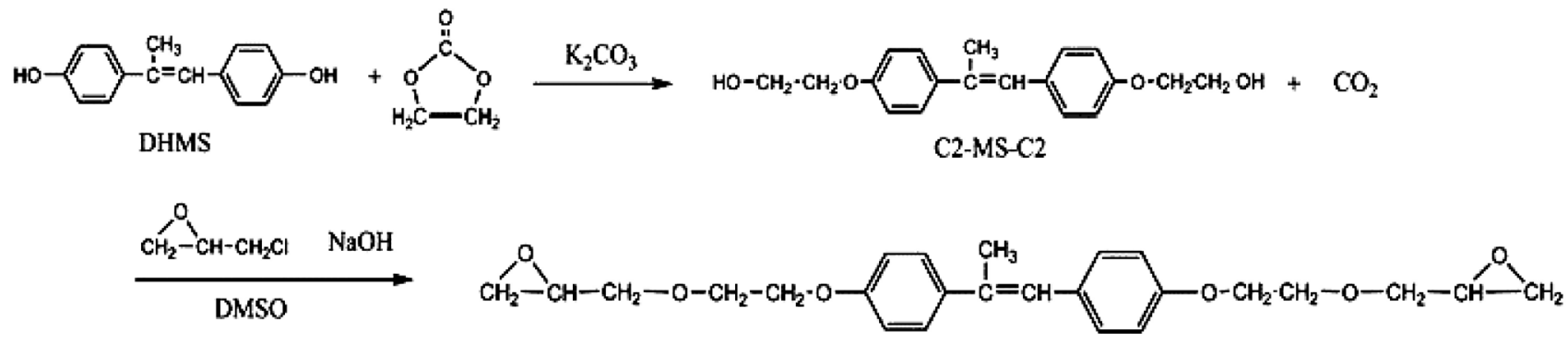

DGE(C2-MS-C2)

図 6 スチルベン骨格の両端にスペーサーを導入したエポキシ（DGE (C2-MS-C2)）の合成 


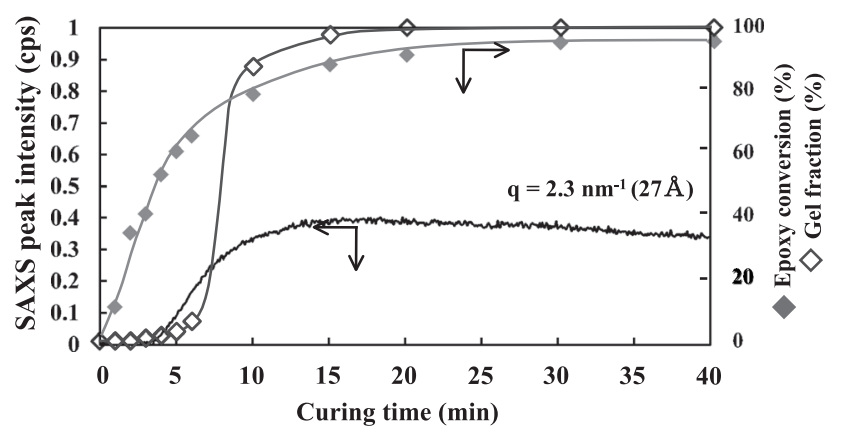

図 8 液晶性エポキシ樹脂の硬化反応過程における小角 X 線 回折ピーク $\left(\mathrm{q}=2.3 \mathrm{~nm}^{-1}\right)$ およびエポキシ基反応率・ ゲル分率の関係

構造最適化によって得られたスメクチック相の層間距離

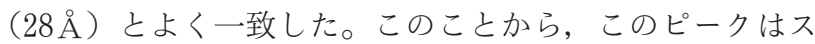
メクチック液晶相の形成に由来するむのと考えられる。ピー ク強度の变化から，硬化時間 3 分経過後からスメクチック 相が形成され始め 15 分時点でほぼ構造形成が完了したも のと考えられる。一方で，偏光顕微鏡観察では，反応開始 後わずか 1 分で液晶相の発現に伴う複屈折パターンが観察 されたことから，反応の初期段階でネマチック液晶が形成 され始め, その後, 反応の進行に伴ってスメクチック液晶 相へ転移しているものと考えられる。ネットワーク形成と 液晶配列との関係について検討したところ，スメクチック 相に起因するピークが出現し始めた時点で，エポキシ反応 率は $60 \%$ ，ゲル分率は $3 \%$ であった。以上のことから， 反応初期で形成されたネマチック相が，ゲル化の進行に伴っ てスメクチック相に転移していると考えられ，ネットワー ク構造を形成し始めることによって分子運動性が制限され， 規則性の高いスメクチック相構造を形成し易くなったもの と考えられる。

このような配向構造を有する硬化物は優れた破壊勒性を 示す ${ }^{15 \sim 20)}$ 。図 9 に示されるように，ドメイン径拡大に伴 う破壊䩚性值の著しい増加が認められ，最大で 10 倍の破 壊鞀性値の向上が達成される ${ }^{15,16)}$ 。また，この破壊䩲性值 の増加は, ドメイン内の液晶配列がネマチック相からスメ

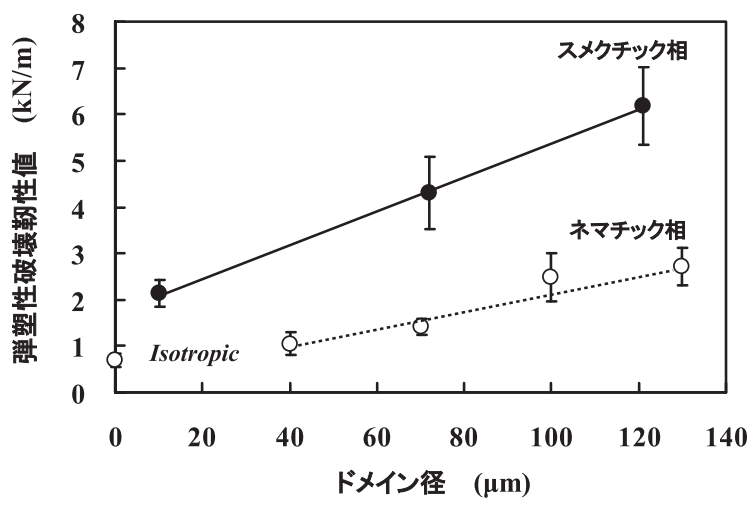

図 9 ポリドメイン硬化物のドメイン径の増大に伴う 破壊勒性变化
クチック相に向上するのに伴ってより顕著となる。配向構 造過程の詳細な追跡によって，構造制御に関する条件の最 適化が実現できれば，このような物性に優れた硬化系の調 製が容易になるものと考えられる。

\section{5. シクロヘキセン構造を含む低融点型液晶性エポキシ}

筆者らはメソゲン基としてターフェニル構造の一部をシ クロヘキセン環に替えた，ジフェニルシクロヘキセン型エ ポキシ樹脂（DGEDPC）の合成について報告している (表 2 ${ }^{21,22)}$ 。DGEDPC は, メチル分岐を有する夕ーフェ ニル型エポキシの融点 $\left(176^{\circ} \mathrm{C}\right)$ に比べ， $80^{\circ} \mathrm{C}$ 以上の大 幅な融点の低下を示す。これによって，比較的低い硬化温 度を設定できるため，従来の問題点であった高温硬化によ るゲル化の速さが抑えられ，ハンドリング性の改善に効果 的である。このモノマーの大きな特徵は，低融点と広範な 液晶相発現温度を両立可能な点にある（95〜 $174^{\circ} \mathrm{C}$ ：スメ クチック $\mathrm{A}$ 相, $174 \sim 199^{\circ} \mathrm{C}$ : ネマチック相)。これによっ て，硬化温度や硬化剂の選択幅が広がるだけでなく，目的 の配列構造の安定的形成が可能となる。芳香族アミンを用 いて硬化した系に打いては, 熱伝導率がスメクチックポリ ドメイン硬化物では $0.39 \mathrm{~W} / \mathrm{m} ・ \mathrm{~K}$ であり，汎用のエポキ シ樹脂の值（ $0.2 \mathrm{~W} / \mathrm{m} ・ \mathrm{~K} ）$ に比べ 2 倍となった。さらに $1 \mathrm{~T}$ で磁場硬化したスメクチック一軸配向硬化物では，配 向方向に高熱伝導率が確認された。この系の配向度は 0.79 となっており，高配向した網目鎖の共有結合方向に熱伝達 効率が高いことを示している。

また，DGEDPCのシクロヘキセン環をシクロヘキサン 環にした，ジフェニルシクロヘキサン型エポキシモノマー

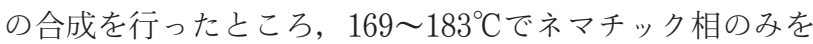
示した。これに対して四環型のジメチルジフェニルジシクロ

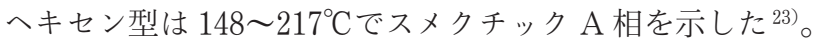
これらのことから，融点の低下とメソゲン基の配列性の両 立には，メソゲン基中央部へのシクロヘキセン構造の導入

表 2 低融点型液晶性エポキシ樹脂 DGEDPC/DDM 系の 熱伝導率

\begin{tabular}{|c|c|c|c|}
\hline \multirow{2}{*}{$\begin{array}{c}\text { 液晶相構造 } \\
\text { (スメクチック相) }\end{array}$} & \multirow{2}{*}{$\begin{array}{c}\text { ポリドメイン配向 } \\
\text { (無磁場) }\end{array}$} & \multicolumn{2}{|c|}{ 一軸配向 (1T) } \\
\hline & & 垂直方向 & 平行方向 \\
\hline & $\begin{array}{l}30 \\
34 \\
3\end{array}$ & 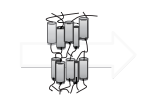 & 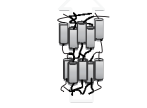 \\
\hline $\begin{array}{c}\text { 熱拡散率 } \\
\left(\times 10^{-5} \mathrm{~cm}^{2} / \mathbf{s}\right)\end{array}$ & $257 \pm 27.4$ & $244 \pm 15.1$ & $578 \pm 12.2$ \\
\hline 密度 $\quad\left(\mathrm{g} / \mathrm{cm}^{3}\right)$ & $1.225 \pm 0.01$ & $1.234 \pm 0.01^{1)}$ & $\mathbf{1 . 2 3 4} \pm \mathbf{0 . 0 1}{ }^{1\rangle}$ \\
\hline 比熱 $(J / g \cdot K)$ & $1.24 \pm 0.02$ & $1.24 \pm 0.02^{1)}$ & $1.24 \pm 0.02^{1)}$ \\
\hline $\begin{array}{l}\text { 熱伝導率 } \\
(\mathrm{W} / \mathrm{m} \cdot \mathrm{K})\end{array}$ & $0.39 \pm 0.07$ & $0.38 \pm 0.05$ & $0.89 \pm 0.05$ \\
\hline
\end{tabular}

DGEDPC 
が有効であることが示唆された。

\section{6. 配列構造形成を利用した高熱伝導コンポジット の調製}

実用的な熱伝導率を得るためには, $\mathrm{Al}_{2} \mathrm{O}_{3}$ や $\mathrm{BN}$ などの 高熱伝導性フィラーとの複合化が必須である。高熱伝導率 を達成するためには，主として熱伝達を担うフィラーの熱 伝達パス形成が必須となり，一般的にはフィラーが大量 （70vol\%以上）充填されるが，粘度上昇や脆化が問題とな る。そのため, コンポジット系内に効率的にフィラーを配置 することで，低含有量での熱伝導パスの形成を実現し，高 熱伝導化を達成する研究が多く報告されている。He ら ${ }^{24}$ は，エポキシ樹脂を若干反応させたものを粉砕し， $\mathrm{Si}_{3} \mathrm{~N}_{4}$ と混合硬化することによって，マトリックス中に網目のよ うにフィラー連続相を形成させたコンポジットが低含有量 で高熱伝導を示すことを報告している。

筆者らは，液晶性エポキシ樹脂を用いた系において，液 晶ドメイン形成過程で BN フィラーをドメイン外に排除 した構造を形成可能なことを明らかにした ${ }^{25)}$ 。図 10 にフィ ラー含有量に対する各コンポジット系の熱伝導率の变化を 示す。未充填のマトリックス単独で比較すると，等方相 $(0.35 \mathrm{~W} / \mathrm{m} ・ \mathrm{~K})$ に比べ, 液晶相硬化物 $(0.38 \mathrm{~W} / \mathrm{m} ・ \mathrm{~K})$ の方が高い熱伝導率を示した。これは，メソゲン基の配列 による液晶ドメイン構造形成の影響であると考えられる。 また，フィラー充填量の増加に伴い，等方相系では熱伝導 率が直線的に増加したのに対し，液晶相硬化系では $18 \mathrm{vol} \%$ 付近から急激な増加傾向を示した。さらに，35vol\%にお いて，等方相系では $1.5 \mathrm{~W} / \mathrm{m} ・ \mathrm{~K}$ であったのに対し，液 晶相系では $2.2 \mathrm{~W} / \mathrm{m} ・ \mathrm{~K}$ と約 1.5 倍高い熱伝導率を示し た。マトリックスのドメイン形成によって，ドメイン間に 排除された $\mathrm{BN}$ フィラーの連続相が生じやすくなったこ とが大きく寄与しているあのと考えられる。これらのこと から，マトリックスに液晶相硬化物を用いることで，メソ ゲン基の自己組織化によるドメイン形成時の駆動力が働き, ドメイン外にフィラーを配置した構造が形成された。これ

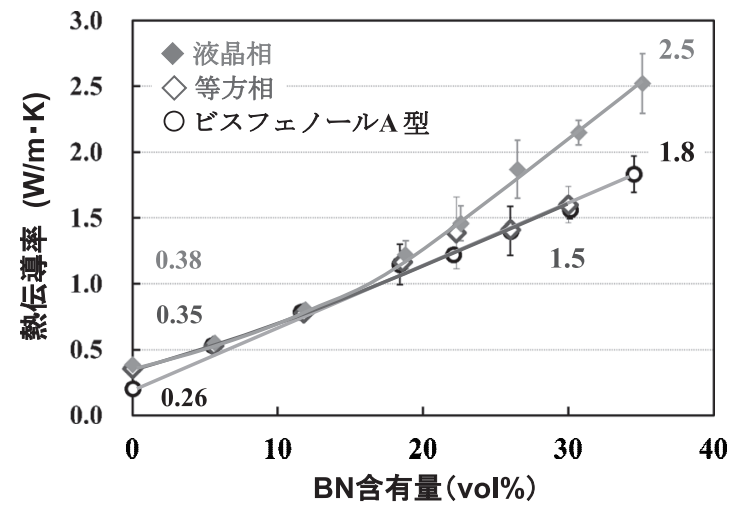

図 10 マトリックスの配列構造の異なる BN コンポジットの 熱伝導率
によって，フィラーによる熱伝達パスが生じやすくなり， 等方相硬化系に比べ，液晶相硬化系は優れた熱伝導性を示 したと考えられる。

\section{7.おわりに}

従来のエポキシ樹脂に比べ，特徵的なネットワーク構造 を形成する液晶性エポキシ樹脂を用いることによって，剛 直構造に起因する耐熱性の大幅な改善や高強勒性や熱伝導 性付与などが可能であることを紹介した。今後も益々拡大 する要求性能を満足するためには，引き続き多様な構造設 計が重要であると考えられる。

\section{文献}

1）エポキシ樹脂技術協会，“総説エポキシ樹脂 基礎編 I・II ” (2003).

2) A. Shiota, C. Ober, Polymer, 38, 5857 (1997).

3) W. Mormann, M. Brocher, P. Schwarz, Macromol. Chem. Phys., 198, 3615 (1997)

4) W. Liu, C. Carfagna, Macromol. Rapid Commun., 22, 1058 (2001).

5) H.J.Sue, J.D. Earls, et al., J. Mater. Sci., 32, 4039 (1997).

6）有田和郎，エレクトロニクス実装学会誌，16, 352 (2013).

7）原田美由紀, 森岡大智, 越智光一, 第 24 回マイクロエレク トロニクスシンポジゥム論文集，p. 159 (2014).

8）原田美由紀，横山有吾，越智光一，第 64 回高分子学会年次 大会予稿集, $1 \mathrm{Pe} 047$ (2015)

9) E. J. Choi, H. K. Ahn, et al., Polymer, 41, 7617 (2000).

10）原田美由紀，松本真実，越智光一，山本久尚，第 56 回高分 子討論会予稿集, p. 4328 (2007).

11) H. Yamamoto, A. Fujita, M. Harada, M. Ochi, Mol. Cryst. Liq. Cryst., 588, 41 (2014).

12) H. Wang, Y. Zhang, L. Zhu, et al., J. Therm. Anal. Calorim., 103, 1031 (2011).

13) Y. Xiao, L. Cao, J. Feng, L. Yuan, J. Appl. Polym. Sci., 126, 527 (2012).

14） M. Harada, J. Ando, S. Hattori, S. Sakurai, N. Sakamoto, et. al., Polym J, 45, 43 (2012).

15) M. Harada, K. Aoyama and M. Ochi, J. Polym. Sci. Part B: Polym. Phys., 42, 4044 (2004).

16) M. Harada, K. Aoyama and M. Ochi, J. Polym. Sci. Part B: Polym. Phys., 43, 1296 (2005).

17) Ortiz, C. K. Ober, et. al., Macromolecules, 31, 4074 (1998).

18) Carfagna, et. al., Macromol. Symp., 148, 197 (1999).

19) M. Harada, K. Sumitomo, Y. Nishimoto and M. Ochi, J. Polym. Sci., PartB; Polym. Phys., 47, 156 (2009).

20) M. Harada, N. Okamoto, M. Ochi, J. Polym. Sci. Part B: Polym. Phys., 48, 2337 (2010).

21）原田美由紀，池尾康宏，服部聖也，越智光一，第 22 回マイ クロエレクトロニクスシンポジゥム論文集，p. 105 (2012).

22）原田美由紀，川崎裕介，越智光一，第 65 回高分子学会年次 大会予稿集，1Pc049（2016）.

23）原田美由紀，川崎裕介，森岡大智，越智光一，第 63 回高分 子学会年次大会予稿集, p. 1531 (2014).

24) H. He, R.Fu, et al., J. Electro. Packaging, 129, 469 (2007).

25) M. Harada, N. Hamaura, M. Ochi, Composites. Part B: Engineering, 55, 306 (2013). 